\title{
DEVELOPMENT OF LEARNING MEDIA FOR THE COURSE OF TWO-STROKE GASOLINE MOTORS TO IMPROVE STUDENTS' LEARNING OUTCOMES
}

\author{
${ }^{1}$ Suyitno, ${ }^{2}$ Iis Widianto, ${ }^{3}$ Suryaneta binti Masrul \\ ${ }^{1,2}$ Study Program of Automotive Engineering Education, Universitas Muhammadiyah Purworejo, Indonesia \\ ${ }^{3}$ Department of Education, National University of Tainan, Taiwan \\ E-mail: yitno@umpwr.ac.id
}

\begin{abstract}
Learning media of cylinder head cutting for 2-stroke gasoline motors are still limited. The students usually receive the materials only from lectures while the practices used uncut motorcycle props. Subsequently, the students hardly understand the form and the functions of the components. This study aimed at (1) developing the instructional media of two-stroke gasoline motors to improve the students' learning outcomes, and (2) analysing the feasibility of the developed instructional media. This study was Research and Development. The subject of this study consisted of the $2^{\text {nd }}$-semester students of Universitas Muhammadiyah Purworejo in the academic year of 2016/2017. The data collection used a questionnaire and a test. The data were analysed using a descriptive analysis technique. The research results showed (1) the developed instructional media was feasible to be applied as instructional media, and (2) the data analysis results of the control class and the experiment class reached the mean scores of 75.80 and 83.25 respectively. It means there was a significant difference between students using the developed instructional media and those who did not.
\end{abstract}

Keywords: gasoline motorcycle, instructional media , learning outcome

\section{INTRODUCTION}

Generally, the goal of education is to provide an environment for students to develop their talents and abilities. It means education functions in accordance with the needs of the students itself and their society. Moreover, the quality of human resources will increase if it has a strong foundation of intellectual, religion, and moral. The purpose of Education is to instill science, skills, and noble values so that human beings can improve their ability in living (Ghozali, 2010). The philosophy of vocational education based on essentialism view state that vocational education should relate to other systems such as the economy, labor, social, and so forth (Djojonegoro, 1998). If it is linked to the economy, it is expected to improve the quality. If it is linked to labor, it can be a supplier of the existing workforce in the corporate world and the industrial world. With social sector, it can be a social change that makes people have a prosperous life.

Pavlova (2009) clarifies that vocational education covers the specific training that can be used in the working world. In line with this view, the concept of Investment in Human Capital states that education, training, or other forms of human investment include the gaining of science, values, and skills make people can improve their learning capacity and productivity, which enable them to pursue higher Education (Becker, 1975). Wulandari et al. (2015) add that vocational education primarily prepare the graduates to work according to their respective fields.

The success of vocational education cannot be separated from the role of learning media. The term of media and mediator is often used interchangeably, where the last is related to the causes or tools that intervene two parties and reconcile between them (Fleming in Arsyad, 2013). Meanwhile, Daryanto (2016) suggests that learning media is anything that can be used to channel the message (learning materials), so it can stimulate students' attention, interest, thought, and feelings in learning activities to achieve the learning goals. It is supported by Crow \& Crow in Wahab (2016) who assert that learning is the acquisition of habits, knowledge, and attitudes including current strategies of doing things and 
one's efforts to overcome obstacles or adjusting to new situations. Suyitno (2016) suggests that learning describes a progressive change in a person's behavior when reacting to the demands confronting him and it enables him/her to center an attention or to reach a goal.

The interview results with the lecturers of Gasoline Motor Technology of Universitas Muhammadiyah Purworejo on December 16, 2016 revealed that the low students' learning outcomes were caused by the absence of learning media of cylinder head cutting for 2stroke gasoline motor for the practice activity. The students usually receive the material only from the classroom lecture while the practice was using motorcycle props that had not been cutting. It made the students still confused because they did not understand the form and the functions of the component as explained by the lecturers.

This condition is interesting to be investigated in order to find the solution since the mastery of cylinder head overhaul material for 2-stroke gasoline motor is a compulsory skill for all students of the Department of
Automotive Engineering, Faculty of Teachers Training and Educational Sciences. However, there is limited number of media for the 2stroke cutting motor. The use of learning might be an effort to optimize the students learning the process. Based on the problem above, this study is trying to develop the learning media for 2-stroke gasoline motor to improve the learning outcomes among the students of Universitas Muhammadiyah Purworejo in the academic year of 2016/2017. This study aimed at (1) developing the instructional media of two-stroke gasoline motor to improve the students' learning outcomes of Universitas Muhammadiyah Purworejo, and (2) analysing the feasibility of the developed media.

\section{METHOD}

This study was designed as Research and Development. It used the research method with nine steps of development procedures. The research procedure adapted from Sugiyono (2015) with modifications is illustrated in Figure 1.

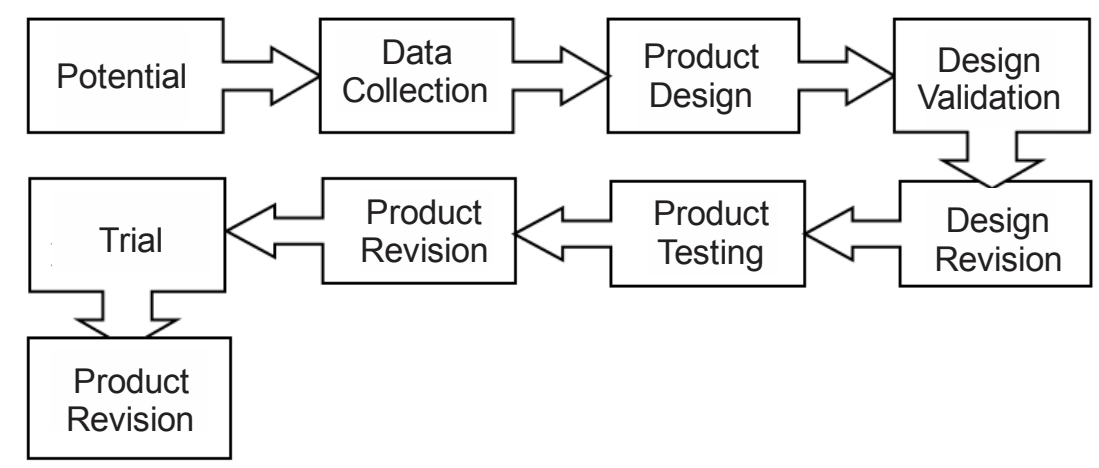

Figure 1. The Stages of Research and Development (R \& D)

This study was based on the potential or problems. Potential referred to anything that can be utilized to have an added value of the product being studied. The problems in this Study were the absence of interesting learning media. The existing learning media was still in the forms of traditional presentations without considering its interactivity and creativity. Universitas Muhammadiyah
Purworejo already had a workshop that met the required standards for learning. By having the learning media, it was expected to improve the learning quality and it can optimize the use of facilities and infrastructure. After the potentials and the problems can be demonstrated factually, it was necessary to collect various information that can be used as material to plan specific products to solve the 
problem. The information was collected by taking all the information from the observations in Universitas Muhammadiyah Purworejo in March 2017.

The product of this study was in the form of Stand Trainer media containing 2-stroke gasoline motor. The media were made using the tools and materials, which were expected to be used to improve the productivity. Design validation is an active process to assess whether the product design, in this case, new working system more effective than the traditional one. Rationally, the validation was still in the form of the validator assessment, i.e. lecturer of Universitas Muhammadiyah Purworejo based on rational thinking. After product design was validated by experts, several weaknesses were known. The weakness was then tried to be reduced by improving the design.

Testing can be done through experiment by comparing its effectiveness and efficiency of the new working system. Product testing on the limited sample showed that the performance of the new system was better than the old system. The differences were so significant, meaning that the new work system can be implemented. After the product testing was successful, the product in the form of a net working system was applied in real conditions for a wider scope. Product revision was conducted if, in the improvement of real conditions, there were deficiencies and advantages. In the trial, the product should be always evaluated on the product performance, in this case, the working system. This study was conducted in Universitas Muhammadiyah Purworejo from May until June 2017. The subject of this study was the second-semester students who joined 2Stroke Gasoline Motor of Automotive Engineering, Faculty of Teachers Training and Educational Sciences, Universitas Muhammadiyah Purworejo.

Data analysis techniques included data interpretation and data processing. In learning media development, it can be considered successful and in accordance with the criterion level if the score reached $60 \%$, then the learning media can be used as instructional media in teaching and learning activities (Sudjana, 1990). In calculating the questionnaire item, A, $\mathrm{B}, \mathrm{C}$, and $\mathrm{D}$ means the the obtained scores were $4,3,2$, and 1 respectively. To make the conclusion, it was used the media validation criteria presented in Table 1.

Table 1. Media Validation Criteria

\begin{tabular}{ccc}
\hline $\begin{array}{c}\text { Interpretation } \\
\text { Criteria }\end{array}$ & Percentage & Criteria \\
\hline A & $80 \%-100 \%$ & Valid \\
B & $60 \%-79 \%$ & Fair \\
C & $50 \%-59 \%$ & Less Valid / Revision \\
D & $<50 \%$ & Invalid \\
\hline
\end{tabular}

The formula for analyzing the response data from media experts and material experts as follows:

$$
\text { Final score }=\frac{\text { the respondent's score }}{\text { the final score }}
$$

Before the T-Test, prerequisite analysis test was required, i.e. the normality test and homogeneity test. Normality test was used to determine the distribution of the research data. In the study, to determine the normality using Kolmogorov Smirnov test. Testing criterion was if p-value (sig) higher than 0.05 then the distribution was normal and if $p$ (sig) less than 0.05 then it was not normal. If the data was not normal, then, non-parametric statistical technique, i.e. Wilcoxon Rank Test was applied. Homogeneity test was used to determine the similarity of two variable of the data Group, i.e. Levene Test. The test criterion 
was if the p-value (sig) higher than 0.05 then the data group met the assumption of homogeneity but if $\mathrm{p}$ (sig) higher than 0.05 then it did not fulfill the homogeneity assumption.

If the data was not homogeneous then Ttest was using a nonparametric statistical technique, namely Wilcoxon Rank Test test. The t-test was used to compare the outcomes of the experimental group and control groups. The formula was the following:

\section{RESULTS AND DISCUSSION}

Material expert validation assessed that the media is good and ready for field testing. It means the material can be tested to prove that the validation has been feasible for data collection. It made the researchers more optimistis that the material can improve the student learning outcomes of the second semester of Automotive Engineering, Faculty of Teachers Training and Educational

$$
t=\frac{M_{X}-M_{Y}}{\sqrt{\left(\frac{\sum_{X^{2}}+\sum_{Y^{2}}+N_{Y}-2}{N_{X}}\right)\left(\frac{1}{N_{X}}+\frac{1}{N_{Y}}\right)}}
$$

Where

$\mathrm{M}=$ the mean score per group

$\mathrm{N}=$ the subject's number

$\mathrm{X}=$ deviation of $X_{2}$ and $X_{1}$ score

$\mathrm{Y}=$ deviation of $y_{2}$ score from the mean of $y_{1}$

Sciences, Universitas Muhammadiyah Purworejo. The media were also validated by media experts to assess the media feasibility. The validation from the media expert obtained $88.8 \%$. The data validation criteria were $88.8 \%$ where it can be considered as fair. In general, media experts assessment on the media was good and worthy for trial to the next stage. The results of the validation of materials and media experts are presented in Table 2 and Table 3.

Table 2. The Result of the Validation from Material Experts

\begin{tabular}{|c|c|c|c|c|}
\hline No & Indicator & Criteria & Score & $\%$ \\
\hline 1 & The appropriateness of the material and the media & $\mathrm{A}$ & 4 & 100 \\
\hline 2 & $\begin{array}{l}\text { The appropriateness of the material and the media } \\
\text { use }\end{array}$ & B & 3 & 75 \\
\hline 3 & $\begin{array}{l}\text { The appropriateness of the material and media } \\
\text { display }\end{array}$ & B & 3 & 75 \\
\hline 4 & The ease of understanding the material & B & 3 & 75 \\
\hline 5 & $\begin{array}{l}\text { The ease of understanding the material with the } \\
\text { media }\end{array}$ & B & 3 & 75 \\
\hline 6 & The ease of material for students to be explored & B & 3 & 75 \\
\hline 7 & The time efficiency of the material explanation & A & 4 & 100 \\
\hline 8 & $\begin{array}{l}\text { The time efficiency of the material explanation with } \\
\text { the learning goals }\end{array}$ & A & 4 & 100 \\
\hline 9 & Material efficiency based on media & A & 4 & 100 \\
\hline 10 & The clarity of the material & B & 3 & 75 \\
\hline 11 & $\begin{array}{l}\text { The material appropriateness of the media with the } \\
\text { students }\end{array}$ & $\mathrm{B}$ & 3 & 75 \\
\hline 12 & The material appropriateness with the lesson plan & A & 4 & 100 \\
\hline 13 & The material appropriateness with the syllabus & A & 4 & 100 \\
\hline 14 & The material coverage & A & 4 & 100 \\
\hline & Total & & 52 & \\
\hline & SM & & 60 & \\
\hline & Mean & & 3.4 & \\
\hline & Percentage & & 86.6 & \\
\hline & Classification & & Baik & \\
\hline
\end{tabular}


Table 3. The Result of the Validation from Media Experts

\begin{tabular}{clccc}
\hline No & \multicolumn{1}{c}{ Indicator } & Criteria & Score & $\%$ \\
\hline 1 & The material appropriateness & $\mathrm{B}$ & 3 & 75 \\
2 & The completeness & $\mathrm{B}$ & 3 & 75 \\
3 & The whole display & $\mathrm{A}$ & 4 & 100 \\
4 & The clarity & $\mathrm{A}$ & 4 & 100 \\
5 & The design & $\mathrm{B}$ & 3 & 75 \\
6 & The simplicity & $\mathrm{A}$ & 4 & 100 \\
7 & The design integrity & $\mathrm{A}$ & 4 & 100 \\
8 & The balance & $\mathrm{B}$ & 3 & 75 \\
9 & The form and size & $\mathrm{A}$ & 4 & 100 \\
& Total & & 32 & \\
& SM & & 36 & \\
& Mean & & 3.5 & \\
& Percentage & & & \\
& Classification & & Good & \\
\hline
\end{tabular}

The media expert validation had given input by stating continue meaning that the developed media can be tested in the field to prove that the validation of the media was suitable for data collection. The implementation of the final product was carried out by involving 30 students on May 29, 2017. The test consisted of 10 items that must be filled.

Based on the data processing from media expert above, it was obtained the score of $86.6 \%$. Then, the media was determined in the form of Stand for the learning model of 2-stroke gasoline motor. The material expert also gave some suggestions such as the material enrichment for the students, material arrangement system, and the material completeness.

Based on the trial, overall, it can be concluded that the learning media was considered as good and the validation criteria of $85.3 \%$ considered as valid. Compared with the previous trial, there was a significant increase in the scores and the categories. The students' response to the media is presented in Table 4.

Table 4. The Students' Response to the Media

\begin{tabular}{|c|c|c|c|c|}
\hline No & Indicator & Score & $\%$ & Category \\
\hline 1 & $\begin{array}{l}\text { Understanding the material of 2-stroke } \\
\text { gasoline motor }\end{array}$ & 79 & 79 & Good \\
\hline 2 & Understanding the language & 86 & 86 & Good \\
\hline 3 & $\begin{array}{l}\text { Gaining a new knowledge of 2-stroke } \\
\text { gasoline motor }\end{array}$ & 88 & 88 & Very Good \\
\hline 4 & $\begin{array}{l}\text { The influence of figure and dan } \\
\text { background on the clarity of the } \\
\text { material }\end{array}$ & 83 & 83 & Good \\
\hline 5 & the clarity of the material & 79 & 79 & Good \\
\hline 6 & The timing of material presentation & 84 & 84 & Good \\
\hline 7 & $\begin{array}{l}\text { The feeling after the learning } \\
\text { implementation }\end{array}$ & 80 & 80 & Good \\
\hline 8 & $\begin{array}{l}\text { The media influence towards the } \\
\text { pleasure of learning }\end{array}$ & 91 & 91 & Very Good \\
\hline 9 & The attractiveness of the media & 97 & 97 & Good \\
\hline 10 & The clarity of narrator's voice & 86 & 86 & Very Good \\
\hline & Total & 853 & & \\
\hline & SM & 1000 & & \\
\hline & Percentage & 85.3 & & \\
\hline & Mean & 3.41 & & \\
\hline & Classification & Good & & \\
\hline
\end{tabular}


This study showed the difference in the effect of the media use in improving students' learning outcomes in the of two-stroke Gasoline Motor course of Automotive Engineering, Faculty of Teachers Training and Educational Sciences, Universitas Muhammadiyah
Purworejo in the academic year of 2016-2017. The summary of the statistical results from the experimental class and the control class can be seen in Table 5. In addition, the chart of the learning results of the control class and the experiment class is illustrated in Figure 2.

Table 5. The Summary of Statistical Result of the Experimental Class and the Control Class

\begin{tabular}{lcc}
\hline \multicolumn{1}{c}{ Statistical Indicator } & Control Class & Experiment Class \\
\hline Mean & 75.80 & 83.25 \\
Highest Score & 90.00 & 95.00 \\
Lowest score & 55.00 & 65.00 \\
Standard Deviation & 4.05 & 4.21 \\
\hline
\end{tabular}

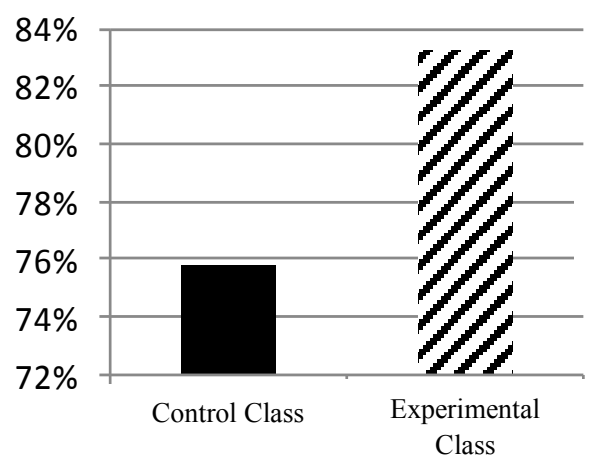

Figure 2. The Learning Results of the Experimental Class and the Control Class

The control class used the lecture method with the powerpoint media and the experimental class was using the standing media. It can be seen that the difference between the mean score and the learning completeness was very significant. It proved that the learning media give the positive influence on the student learning outcomes. The results on normality tests in Kolmogorov Smirnov is presented in Table 6. It showed $\mathrm{p}=$ 0.658 , since $\mathrm{p}$ higher than 0.05 , it meant both groups are normally distributed.

Table 6. Normality Test of Learning Results of the Experimental Class and the Control Class

\begin{tabular}{|c|c|c|c|c|c|c|c|}
\hline \multirow[b]{2}{*}{ Class } & & \multicolumn{3}{|c|}{ Kolmogorov-Smirnov ${ }^{\mathrm{a}}$} & \multicolumn{2}{|c|}{ Shapiro-Wilk } & \multirow[b]{2}{*}{ Sig. } \\
\hline & & Statistic & df & Sig. & Statistic & df & \\
\hline \multirow[t]{2}{*}{ Score } & Eksperiment & .267 & 30 & .658 & .843 & 30 & .256 \\
\hline & Control & .150 & 30 & .082 & .949 & 30 & .156 \\
\hline
\end{tabular}

Table 7, Table 8 and Table 9 show the results of the homogeneity Test, the T-test and description and learning results respectively. The results of an independent sample T-test on the homogeneity variable test showed that $\mathrm{F}_{\text {count }}$ is 1.004 and $\mathrm{F}$ table is 2.217 with the score of $\mathrm{p}$ is 0.788 , since $\mathrm{p}$ is higher than 0.05 , it meant both groups had a homogeneous variable that made $t_{\text {count }}$ was classified on the equal variance assumed. The result of the T-test used independent sample $\mathrm{T}$ test technique which obtained $t$ count was 4.849 
with the score of $\mathrm{p}=0.000$ which is less than 0.05 and it indicated the difference on of the experiment class and control class where the mean of the experiment class was significantly higher than the control class.

Table 7. Homogeneity Test Results

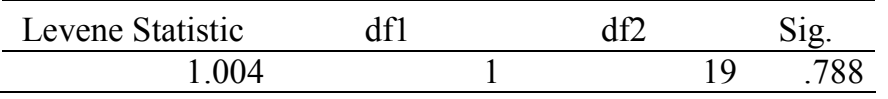

Table 8. The T-test on the Learning Results of the Experimental Class and the Control Class

\begin{tabular}{|c|c|c|c|}
\hline & \multicolumn{2}{|c|}{ Learning Motivation } \\
\hline & & $\begin{array}{c}\text { Equal variances } \\
\text { assumed }\end{array}$ & $\begin{array}{c}\text { Equal variances not } \\
\text { assumed }\end{array}$ \\
\hline Levene's Test for Equality of & $\mathrm{F}$ & 1.004 & \\
\hline Variances & Sig. & .788 & \\
\hline t-test for Equality of Means & $\mathrm{T}$ & 4.849 & 4.849 \\
\hline & Df & 58 & 55.996 \\
\hline & Sig. (2-tailed) & .000 & .000 \\
\hline & Mean Difference & 10.00000 & 10.00000 \\
\hline & $\begin{array}{l}\text { Std. Error } \\
\text { Difference }\end{array}$ & 2.06225 & 2.06225 \\
\hline & 95\% Confidence & 4.60034 & 4.60034 \\
\hline & $\begin{array}{l}\text { Interval of the } \\
\text { Difference }\end{array}$ & 14.13119 & 14.13119 \\
\hline
\end{tabular}

Table 9. Description and Learning Results

\begin{tabular}{lllcccc}
\hline \multicolumn{1}{c}{ Class } & $\mathrm{N}$ & Mean & $\begin{array}{c}\text { Deviation } \\
\text { Standard }\end{array}$ & $\mathrm{T}$ count & $\mathrm{sig}$ & $\mathrm{t}_{\text {tabel }}$ \\
\hline Experiment & 20 & 83.25 & 4.21 & 3.93 & 0.00 & 1.71 \\
Control & 20 & 75.80 & 4.05 & & & \\
\hline
\end{tabular}

T-test results with independent sample Ttest technique obtained $t$ count was 3.93 which is higher than $\mathrm{t}$ table 1.71 , it meant there was a difference in the learning outcomes of the experimental and control class where the mean score of the learning outcomes from experiment class was significantly higher than the control class.

Dittrich (2009) suggests that an educator has the role of social worker, psychologist, mediator, communicator, team worker, knowledge networker, and an expert. The meaningful of learning also need to be supported by students who possess the motivation and the accuracy of learning media. This developed media may facilitate the educators with these demands. Moreover, Wibawa (2005) utters that competence is a basic characteristic consisting of knowledge, attitude, and skills and other personality attributes that are able to distinguish a person's work with high and low performance in a particular job. With the study on the development of gasolin motor media, it can be said to be competent because the students performed better mastery after using the media. Purwanto (2007) states that learning outcomes can be interpreted as the students' level of success in learning the subject matter in the school through the obtained scores from the test results It is simply said that the students' learning outcomes are the obtained ability by the child after been through learning activities. In the learning activities or instructional activities, teachers usually set the learning goals. Successful students in their learning are those who achieve the learning goals or intentional goals. The research results showed that the learning outcomes with the developed media implementation were better. 
This developed media can be used as an alternative source of autonomous learning to overcome the weakness of classical learning. This study showed that the use of learning media had a positive effect on students' learning outcomes. This learning media can be a tool to improve the learning outcomes because, in the large group trials with the number of 20 students, it could improve the student learning outcomes.

\section{CONCLUSION}

The results of product validation by the material experts and media experts, small group trials and product trial showed the product is feasible as learning media.The result of the Ttest with the significant error of $5 \%$ showed that this instructional media was effective to improve the learning outcomes of the second semester students of Automotive Engineering, Faculty of Teachers Training and Educational Sciences, Universitas Muhammadiyah Purworejo. This learning media can be used in learning as a medium to improve the learning outcomes since, in large group trials with the number of 20 students, it can increase the student learning outcomes. To make the product can be utilized optimally, the lecturers should employ varied methods to support the use of instructional media to increase students' interest, motivation and learning outcomes. The educational institutions should apply learning media in all another course of vocational competence and provide the adequate facilities and infrastructure to support the learning media. Meanwhile, the next studies should be more creative to find new ideas in learning media making for effectively improve students' learning outcomes.

\section{REFERENCES}

Arsyad, A. 2013. Media Pembelajaran. Jakarta: Raja Grafindo Persada

Becker, G.S. 1975. Human Capital, A Theoretical and Empirical Analysis with Special
Reference to Education. Washington: National Bureau of Economic Research, Inc.

Daryanto. 2016. Media Pembelajaran. Yogyakarta: Gava Media

Dittrich, J. 2009. Standardisation in TVET Teacher Education. Alle Reche vorbehalten: Peter Lang GmbH.

Djojonegoro, W. 1998. Pengembangan Sumber Daya Manuasia melalui Sekolah Menengah Kejuruan (SMK). Jakarta: Jayakarta Agung Offset

Ghozali, A. 2010. Ekonomi Pendidikan. Jakarta: Lembaga Penelitian UIN Syarif Hidayatullah

Murphy, P. \& Mc Cormick, R. 2008. Knowledge an Practice, Representations, and Identities. London

Pavlova, M. 2009. Technology and Vocational Education for Sustainable Development, Empowering Individuals for the Future. Bonn: Springer

Purwanto. 2007. Evaluasi Hasil Belajar. Yogyakarta: Pustaka Pelajar

Sugiyono. 2015. Metode Penelitian Pendidikan (Pendekatan Kuantitatif, Kualitatif, dan $R$ $\& D)$. Bandung: Alfabeta

Suyitno. 2016. Pengembangan Multimedia Interaktif Pengukuran Teknik Untuk Meningkatkan Hasil Belajar Siswa SMK Yogyakarta. Jurnal Pendidikan Teknologi dan Kejuruan. 23. 1, 101-109

Wahab, R. 2016. Psikologi Belajar. Jakarta: Raja Grafindo Persada

Wibawa, B. 2005. Pendidikan Teknologi dan Kejuruan, Manajemen dan Implementasi nya di Era Global. Surabaya: Kertajaya Duta Media

Wulandari, B., Suparman, Santoso, D. \& Muslikhin. 2015. Pengembangan Trainer Equalizer Grafis dan Parametris sebagai Media Pembelajaran Mata Kuliah Praktik Sistem Audio. Jurnal Pendidikan Teknologi dan Kejuruan. 22. 4, 373-384 